\title{
Current and Historical Application of Knowledge Management in Economy
}

\author{
Eduardo Tomé $\mathrm{a}^{*}$ \\ ${ }^{a}$ Universidade Europeia, Lisbon, Portugal
}

\begin{abstract}
Objectives: The paper tries to analyse the current and historical application of Knowledge Management in the Portuguese Economy, particularly since the democratic revolution of 1974. Methods/Analysis: Study is based in theories about the impacts of knowledge in countries at a micro and a macro scale. A three levels mode is used, related to context (namely 1) Historical background; 2) basic economic and social data: 3) broad vocational education and training (VET) systems; 4) institutional actors; 5) political context), intervention (namely 1) basic legislative documents, 2) guidelines on eligibility, 3) programs, 4) evaluation procedures) and outcomes (namely 1) stocks, investment, and outcomes; 2) price, quantity, supply, demand, equilibria; 3) needs). Data used are statistical published data and other published documents. Findings: The context changed for the better, because after 1974 the country rulers installed a regime in which knowledge was not seen like a luxury but as a basic need; the change in context was also helped by the adhesion to the EU, which in turn led to massive interventions supported by funds like the ESF and the Regional fund; as a result outcomes are finally seen, as the increase in supply and demand of knowledge and also in the income and employability of the Portuguese attests. Novelty/Improvement These findings are important because they depict the slow but sure transformation of Portugal into a Knowledge Economy. Should be complemented by a more detailed analysis, with a larger group of researchers.
\end{abstract}

Keywords:
Portugal;
Knowledge Management;
Context;
Intervention;
Impacts;
Statistics.

$\begin{array}{llll} & \\ \text { Article History: } & \\ \text { Received: } \quad 07 & \text { September } & 2020 \\ \text { Accepted: } \quad 16 & \text { November } & 2020 \\ \text { Published: } \quad 01 & \text { December } & 2020\end{array}$

\section{1- Introduction}

Nowadays (2020), the world lives in a knowledge centered and services driven economy. It is well known that knowledge is, with other intangible assets the main asset of successful economies and economic agents. This reality is exposed by theories and studies that will be listed in section 2. In this context, Portugal is a very special country. A small country with a long history, some consider that it owned its success and reputation of first major global power to masterly use of knowledge and intangibles in the 16th century. In more recent decades Portugal went from the center of a colonial Empire in 1974, to a member of the Eurozone in 2002. This evolution produced massive changes in the country. Therefore, the research question of this paper is: what can be said about the use of KM in Portugal, namely in terms of context, interventions and outcomes? In order to answer this research question, well known concepts and theories (see section 2) and a three stage methodology (see section 3) are used. Accordingly, the paper will have the following structure: 1. Introduction 2. Literature review: namely Concepts (KM and Portugal), Theories (National KM) and similar studies. 3. Methodology and Data. 4. Analysis 5. Discussion. 6 Concluding comments.

\section{2- Literature Review}

\section{2-1-Concepts}

\section{2-1-1- Knowledge Management}

The analysis has two basic levels, depending on the concepts used. There is a large conception of macroeconomic scope according to which KM encompasses education (formal and informal), science, use of technology, company routines, brands, and therefore is about the widespread use of knowledge in societies; this conception is of

\footnotetext{
* CONTACT: Eduardo.tome@gmail.com

DOI: http://dx.doi.org/10.28991/esj-2020-01245
}

(C) 2020 by the authors. Licensee ESJ, Italy. This is an open access article under the terms and conditions of the Creative Commons Attribution (CC-BY) license (https://creativecommons.org/licenses/by/4.0/). 
macroeconomic scope [1]. There is a much stricter conception that looks at the use of knowledge in organizations this conception has a more microeconomic scope [2]. In this paper both conceptions are used. This means that even knowing that the most common conception in KM analysis in Nonaka's, the broad version of the concept will be used, because as the paper addresses the case of a country, a more macro conception is welcome.

\section{2-1-2- Portugal}

Portugal is in geographical terms the western limit of Europe, and has been having almost stable frontiers in the continent since 1297. However, its diplomatic and war history is much more complex and rich, in particular given that the country was the center of a colonial empire since the 15th century which only ended with the instauration of democracy in 1974. Quite crucially, the Discoveries that built the Empire were based on knowledge, but when the non-democratic regime collapsed in 1974, due to a colonial war, the country was facing massive economic and social problems, also due to the low level of knowledge, skills and education among the population [3]. This situation and evolution will be described in section 4.1.

\section{2-2-Theories on KM in Countries}

\section{2-2-1- Micro Effect}

Knowledge is said to have a positive effect in the market returns of individuals, and organizations. That return explains the investment in knowledge meaning that the cost is lower than the benefit. For individuals the benefits may be measured in terms of wages, or a better employment or non-salary benefits like time off. For organizations the benefit may be measured by productivity, sales, wages, or other less tangible ideas like reputation. Individuals may also perceive reputation or power as a consequence of knowledge. Quite crucially, knowledge is an intangible. And many of its benefits may be intangible. But also, many of its costs are intangible, like time, and opportunities missed or given up. This analysis is in fact an extension of Human Capital models [4, 5]. The analysis may have some social implications, but quite interestingly, critical knowledge management is a much little developed notion [6].

\section{2-2-2-Macro Effect}

It is possible to define low, medium and high equilibriums in what concerns the use of knowledge as it happens with the use of skills [7]. In a low equilibrium there is not much investment in knowledge, and there are also not many jobs available that require knowledge. This situation happens in less developed countries and also happened in Portugal at least until the revolution of 1974. On the contrary, in an equilibrium of high levels, people study and acquire lots of knowledge because they know it would be useful, and at the same time companies and organizations make vacancies for knowledge workers because they expect them to be available. This situation exists in the developed countries and in the last years as slowly but gradually began to exist in Portugal, as it will be seen in section 4. In the meantime, however, the country had to break the vicious cycle of the low investment in knowledge and had to create a virtuous cycle. Between the low situation and the high situation. A middle level equilibria exists, in which investment by individuals and organizations exists, but it is not very high. This situation is characteristic of emerging nations. Quite crucially, during the last 40 years. Portugal slowly but surely emerged as a developed country and also surely but steadily increased the use of KM, both things explaining each other.

\section{2-3-Known Studies on KM in Portugal}

The use of KM in Portugal has been receiving some attention by scholars in the last years. At least 79 papers related to the topic may be found in the online literature as per the B-On database, which is used in the Portuguese Universities [8]. Of the mentioned 79 , only a few [9, 10] have macro or even regional [11] or local [12] considerations; rather, most of the papers are management based; some of those papers refer to major problems such as sustainable competitive advantage [13], innovation [14, 15], technology [16, 17]; some of those papers are about MNCs [18, 19], government [20, 21], the health sector [22, 23], the tourism sector [24-26], education [27, 28], biotechnology [29], the textile sector [30], construction firms [31] or the chemical industry [32]. Quite interestingly, much emphasis was put in the relation between Human Resource Management and Knowledge Management [33-36]. This paper intends to be a complement to these analysis.

\section{3- Research Methodology}

A model with three levels of analysis is used. The first level describes the context in which KM operates, and follows [37]; the items addressed are the following: 1) Historical background; 2) basic economic and social data: 3) broad vocational education and training (VET) systems; 4) institutional actors; 5) political context. The second level details the KM policies based in [38, 39]; topics are 1) basic legislative documents, 2) guidelines on eligibility, 3) programs, 4) Evaluation procedures. Finally, in the third and deepest level the outcomes of KM are analysed, in line with [40]; specifically, the following questions are addressed in succession: 1) stocks, investment, and outcomes; 2) 
price, quantity, supply, demand, equilibria; 3) needs. The three levels generate a description of KM in Portugal and enable us to answer the papers research question. The methodology is illustrated by the following Table:

Table 1. Three levels Methodology (flowchart).

Level 1 - Context - Following [37]:
1) Historical background;
2) Basic economic and social data:
3) Broad vocational education and training (VET) systems;
4) Institutional actors;
5) Political context.
Level 2 - Investment and KM Policies - Following [38, 39]:
1) Basic legislative documents,
2) Guidelines on eligibility,
3) Programs,
4) Evaluation procedures.
Level 3 - Outcomes - [40]:
1) Stocks, investment, and outcomes;
2) Price, quantity, supply, demand, equilibria;
3) Needs

\section{4- Analysis}

\section{4-1-Context}

\section{4-1-1- Historical Background}

Portugal is an old country, its Independence having been granted in 1143 . Since 1297 its continental frontiers with Spain, a country with which Portugal shares the Iberian Peninsula and the western part of Europe have been stable. However in the 15th century Portugal embarked in the Discoveries, which gave raise to a big colonial empire that lasted until 1975. That empire made of Portugal the first global power [41].

Quite importantly for this paper, the Empire was based on knowledge and knowledge management: in fact Portugal arrived in India, Brazil and elsewhere, almost everywhere, before any other country, because it had mastered the knowledge of sailing, and of making boats. This scientific advantage, when translate on knowledge use, enabled the Portuguese to achieve important trade businesses first in India in the 16th Century and then in Brazil in the 18th century. There is no doubt that the knowledge base existed that generated both successes [3]. This one is the first big idea that makes Portugal a special case in terms of KM.

The second idea [9], relates that for centuries, and in fact until the 1974 democratic revolution, knowledge in Portugal has been elitist, informal or obtained abroad. The paper will take a moment to explain these three important ideas.

Elitism existed because, despite the fact that Portugal was the birth of two of the oldest Universities in the world, namely in Lisbon and Coimbra, founded by Papal law during the 12th century, the diffusion of knowledge through the population was scarce. In fact, Illiteracy was the norm until the beginning of the 20th century. When the Monarchy was abolished the main political idea of the Republicans was to educate the people, and the man that promoted more that idea (Teófilo Braga), was the first ruler of the country after the 1910 revolution that deposed the King. The efforts of the First Republic were short lived and in 1926 a right wing dictatorship was installed for which 4 years of education was enough and at the same age the kid would become a citizen by having the national identity card. As a consequence as late as 1974, when democracy was finally installed, 16 percent of the population was illiterate, only 1 percent of the population had university studies, the average number of schooling was less than 4 and the country had only 1000 PhDs [42].

Informality existed because for centuries, the vast majority of the Portuguese began their working life at a very young age, and, due to the aforementioned elitism, they had to learn almost everything they needed to know in order to perform well 'on-the-job', informally, without formal classes, and while working. Therefore life was the 'university' the ordinary Portuguese attended [9]. 
Finally, the foreign lands were important because and rather curiously, the Portuguese tended to be extremely successful when they went to work outside their country. From huge personalities like António Guterres (current UN secretary), to Cristiano Ronaldo and José Mourinho (football mega-stars) to ordinary citizens, the Portuguese live through the adage that "no one is prophet in his own land" and therefore at times it seems that in the country, if one wants to earn a good reputation, it has to achieve it abroad. That success is usually achieved by learning and using knowledge abroad. In this context a massive word was coined during the 18th century 'estrangeirado' - meaning one who began to behave like a foreigner; 'estrangeirados' have existed since the 16th century and were very clever persons who, in order to fulfil their own potential, had to work abroad. And of course they learnt a lot of their knowledge abroad.

Moreover, by and large, emigration has been since the Discoveries the solution to Portugal's problems, most recently during the 1960's when more than one million Portuguese migrated and as recently as 2011-2014 when 300 000 citizens, mostly educated and young went out of the country due to recession. In all cases, emigration was a source of knowledge, even if just in time and just in case knowledge to all those people and workers.

All in all, from 1143 to 1974, knowledge was important in Portugal because in one hand it led the country to its biggest success (the Discoveries) but also because it explained the countries' downfall afterwards. That fall was also explained because throughout the ages, knowledge and for the generality of the population, knowledge was elitist, informal and obtained abroad.

\section{4-1-2- Basic Socio-economic Conditions}

The evolution studied in this paper dates from 1974 to current times, and it is very significant. During that period the country's population remained stable, but increased of half a million with the fall of the Berlin Wall, when there was an influx of migrants from the Eastern countries. The gross income and the income per capita increased remarkably after 1986; unemployment however raised from 4 percent in 1988 to 16 percent in 2014, as a consequence of the shock austerity measures caused by the raise in the external debt. The levels of attendance of education raised a lot in the period, most of all in the higher education segment. At the same time, the level of life expectancy raised continuously and sharply and the level of infant mortality decreased abruptly. All those are signs of prosperity. Finally, the Gini Index continued to be high in world terms but decreased, the same happening with the level of poverty. All those data are shown in Table 2, above.

Table 2. Socio-economic conditions in Portugal [43-46].

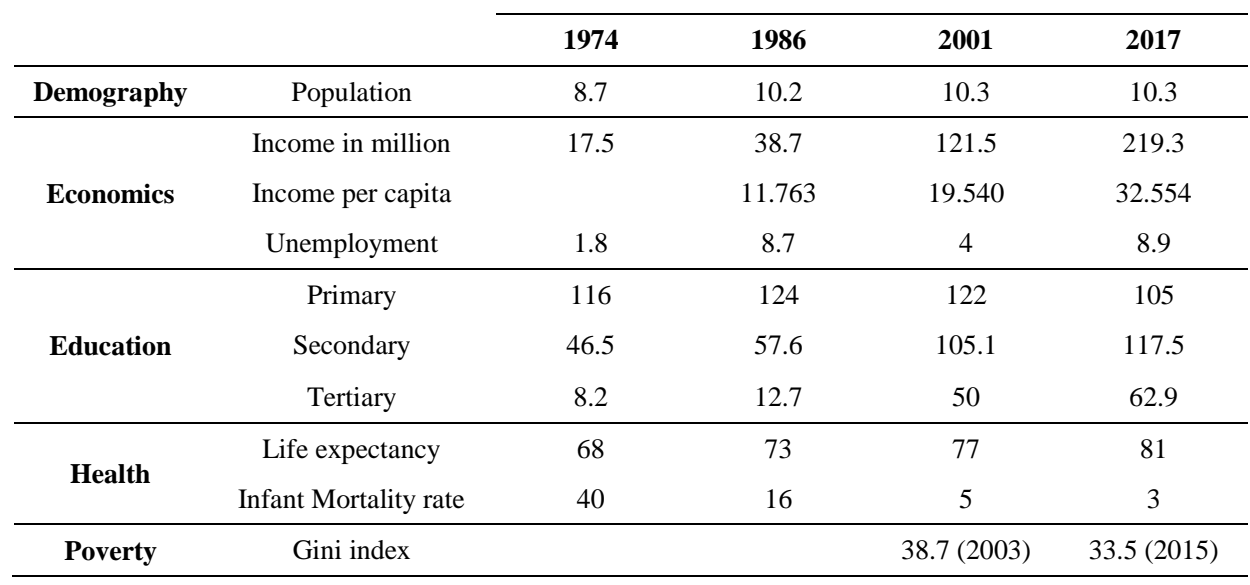

\section{4-1-3- Broad Vocational Education and Training (VET) Systems}

Portugal's system of education was strongly developed in the last four decades. Basic figures that illustrate that change and increase are shown in Table 3. Below. The level of compulsory schooling increased in the period, from almost third world country levels to developed ones (see line 2); quite crucially, that legal change was matched by the increase in the level of education of the younger generations (line 3). All generations considered the attainment of educational degrees rose remarkably (lines 4 to 6). As a result, the average level of schooling increased sharply. Also, Portugal's ranking and rating in the PISA study also increased sharply continuously. All this positive evolution regarding was accompanied with a big increase in the participation rate in training. 
Table 3. Basic data of broad education and training systems [47].

\begin{tabular}{|c|c|c|c|c|c|}
\hline & & \\
\hline & & 1974 & 1986 & 2001 & 2017 \\
\hline Compulsory education & \multirow{2}{*}{ Level } & 4 & 9 & 12 & 12 \\
\hline Average years of education of youth & & 4 & 6 & 9 & 12 \\
\hline \multirow{3}{*}{ Attainment } & Primary & 72 & 92 & 100 & 100 \\
\hline & Secondary & 10 & 30 & 51 & 82 \\
\hline & University & 1 & 10 & 21 & 41 \\
\hline Schooling & Average years & 3.5 & 5.5 & 7 & 9 \\
\hline PISA scores & & & & 459 & 501 \\
\hline Training & Participation rate & 1 & 10 & 20 & 30 \\
\hline
\end{tabular}

\section{4-1-4- Institutional Actors}

The Portuguese Government always had a big role regarding KM in Portugal. Until 1974 the State effectively made the market, conditioning it continuously. After the revolution, democracy brought change and opportunities, but the real change only happened when the EU policies began to be applied, in 1986; not only rules changed, but funds were also available, for education, training, science and organizational routines; in 2001 Lisbon was the place in which the European Strategy for Employment was signed, aiming at putting the EU, in 2010 at the front of the world's knowledge economy.

Big private companies were important, being a support of the regime before 1974, nationalized in 1975, privatized after 1986, and starting to offer quality training and using knowledge more intensively after. They have also funded knowledge investments for their more promising workers. SMEs had almost no training until 1986 and relied on education plus tacit knowledge; in more recent years they have been subject of public programs.

NGOs had almost no expression before 1974 and have become increasingly important, particularly when they tend to replace the State as providers of care, which requires explicit and tacit, formal and non-formal knowledge. Unions were banned before 1974 and had big political significance after; they tried to provide training for their members, but did not succeed capturing the knowledge workers who are basically not unionized.

The employers were not very fast to encourage massively the use of knowledge, as Portugal specialized in the cheaper brands of the textile industry. After that, they tried to profit from the European funds with not big results. Even in very recent years companies were known to try to hire graduates at prices of minimum wage, telling that "If candidate A does not want, another candidate will accept for sure given the crisis". This situation is almost perverse given that the educational and training sector was so much developed in the last 45 years, ending generating a lot of graduates, masters and trainees of good quality. The tourism sector, for instance is a good example of that supply, and of the exploitation of the young workers by the employers.

Before 1974, families had the essential burden to fund the provision of knowledge, and this was very difficult, because the wages were kept low by the employers with the complacency of the political powers - and the country paid a hard price on development grounds. In the last decades economic development, redistribution policy and actions of other actors like the State, the private companies and the EU have tried to make that massive burden smaller.

The elites' role has been mixed - while they encourage their kids to study, still they try to get education abroad. Finally, as since the Discoveries, the external factors have been decisive - before 1974 the Empire and the USA had a large influence; after losing the colonial Empire the country had to face worldwide competition; after 1986 the EU was a way of achieving and creating knowledge in order to achieve prosperity.

\section{4-1-5-Political Context}

KM operations in Portugal in the last five decades were done in a succession of very different political environments. In the old regime, there was a dictatorship, no freedom of speech and rules were enforced through imprisonment of opponents if necessary. The Constitution was from 1932. Then, with the coup d'Etat came a revolution and a new constitution, in 1976, meant to install a socialist regime. This document was reviewed in 1982, 1989 and 1997, ending in the current version which is social democratic with some Conservative rules. During the period the country joined the European communities, later European Union; the EU is in itself a very mixed set of rules but it is not questionable that influenced decisively the KM investments in the country. Finally, in the last years it was very important the dynamic imposed by the Troika Agreement between 2011-4 and in the subsequent period, the reversing of the restrictions the "Troika" rules had imposed. 


\section{4-1-6- Reflection}

In the last forty years, and after a unique history, the context for Knowledge operations improved in the country, regarding the political conditions (knowledge requires dialogue and democracy), the actions of actors (strengthened and more participative), the basic educational rules and actions (both improving strongly) and also the basic economic and social reality, defined by health, poverty or economic indicators. Crucially all this contextual evolution that benefited the use of knowledge was itself helped by the increasing use of knowledge, within a very positive even if long coming and slow virtuous cycle. In the next two subsections the operations (4.2) and the outcomes (4.3) which materialized that societal change, within the context just defined are analyzed.

\section{4-2-Interventions}

\section{4-2-1- Basic Legislative Documents}

Historically, Portugal was always famous for its massive legislative production, but unfortunately in many times those laws were not put in practice; it was a bit because of that disconnection that the country was labelled as a "country of poets" - many words, no action. Quite interestingly, most of the implementation of the knowledge economy in Portugal followed the adhesion of the country to the European Union in 1986. Most important legislative pieces in the process were the guidelines on structural funds, namely the European Social Fund that supported training and science [48], the regional fund, which provided the money for the infrastructures [49], the Erasmus Program on international mobility, and the documents on the Bologna Process [50], that transformed, updated and upgraded the university degrees making them much more flexible.

Those European guidelines complemented some other good ideas from national origin namely the Constitution of 1976, reformulated several times until 2005, that stated education as a right and science as a fundamental activity [51]. Also some laws and namely: a law on the extension of education to end the laws to make university accessible to everyone aged plus of 23 years old regardless of having completed secondary school [52] and the programs of certification on informal competences [53].

\section{4-2-2- Guidelines on Eligibility}

The regime issued from the 1974 revolution was of leftist (socialist and social democratic contours) and the constitution of 1976 and its successive reformulations state that education, training and knowledge as a fundamental right, universal, free of charge and complete [51] - these being the so called Beveridge Principles that build the social democratic welfare states [54]. More than that, equal of opportunities was also assumed as one of the main principles of the Portuguese regime after 1974 and also of the European Union and this generated laws to positive discriminate several specific groups in the access to education, training and knowledge as a whole related initiatives as the young with less than 25 years old during the 80 s and nineties or the middle aged workers in the last decade, due to unemployment pressure [49]. Quite curiously the shift in those less generic guidelines reflected both deep economic concerns and basic political objectives from the successive governments.

\section{4-2-3-Programs}

The development and implementation of the KE in Portugal was fostered by the European Union. Major programs were funded by the ESF [48], and major works by the Regional Fund [49]. National programs existed on recognition of qualifications like Novas Oportunidades [55]. The programs put in place between 2001 and 2010 existed within the scope of the European Strategy for Employment, whose aim was to make Europe the leading force in the Knowledge Economy and that was exposed publically in Lisbon for the first time in 2001, having with mentor a well-known Portuguese Maria João Rodrigues [56]. Furthermore since 2010 the programs have been defined in the scope of the Treaty of Lisbon, which was signed in the Portuguese capital in December of 2007 [57]. All in all the Portuguese did a lot to foster within the EU the implementations of the policies they would use for their benefit regarding the knowledge economy.

\section{4-2-4- Evaluation}

The number of people that achieved the various levels of education rose steadily since 1974, and in succession for primary, low secondary, high secondary and tertiary education [42]. The number of persons involved in the ESF also rose steadily and a market for vocational training was defined; since 1986 around 10 percent of the labor force received training every year [38]. The number of people involved in Erasmus programs also rose steadily, particularly since 2007. In terms of funds, both the budget of the Ministry of Education and the Ministry of Science [42], and the budget of the ESF [38], of the Regional Fund section devoted to science and education [49] and also of the Erasmus Project also rose during the period. Finally evaluation studies have been made that suggest that those investments had positive macroeconomic [58] and microeconomic effects in the country [59], and others that studied the system of provision of knowledge itself [60]. 


\section{4-2-5- Reflection}

The Knowledge economy was implemented in Portugal since the 1974 revolution and above all since 1986 with the institutional and financial support of the European Union. The increase in operations was firstly radical and then steady. The scope was large and the impacts huge. The next section will address the outcomes more in detail.

\section{4-3-Outcomes}

\section{4-3-1-Stocks, Investment, and Outcomes}

All the effort that took place in Portugal since 1974 and particularly since 1986, in order to develop the Portuguese Knowledge Economy, and ultimately to foster Knowledge Management was done with massive investments of the public sector on education, training and science [42]; this important move was accompanied by an increase in the effort of the private sector and the non-private sector [47]. Due to the process of economic development a middle class emerged, particularly from 1986 to 2001 which had more possibility to fund knowledge related investments. And also much investment was done in the supporting elements of knowledge management and the knowledge economy like health, roads and IT infrastructures [42]. All that investment resulted in a big increase in the stock of knowledge of the country, measured in terms of educational degrees, or in terms of skills level of the work force as seen in Table 4.

Table 4. Stocks and outcomes of KM in Portugal (thousands) [42].

\begin{tabular}{ccccc}
\hline $\mathbf{N}$ & $\mathbf{1 9 7 4}$ & $\mathbf{1 9 8 6}$ & $\mathbf{2 0 0 1}$ & $\mathbf{2 0 1 7}$ \\
\hline 9 years & 502 & 751 & 1285 & 1805 \\
12 years & 251 & 523 & 1013 & 1865 \\
University & 90 & 300 & 588 & 1604 \\
Skilled Workers & $\mathrm{Na}$ & 752 & 1061 & 993 \\
Line Managers & $\mathrm{Na}$ & 75 & 165 & 130 \\
Middle Managers & $\mathrm{Na}$ & 35 & 91 & 149 \\
Superior Staff & $\mathrm{Na}$ & 38 & 126 & 212 \\
\hline
\end{tabular}

The outcomes of the investment in Knowledge in Portugal were extremely important. From 1974 to 1986 the economy did not grow much mainly due to the huge turmoil derived from the adjustment to democracy. But, from 1986 to 2001 the country had a "golden decade", with very important social improvements. And, in 2002 the country was in the Eurozone, something that was by all means a success. Afterwards from 2002 to 2014 the country went through a succession of crisis, which was surpassed from 2015 to 2019.

\section{4-3-2- Demand, Supply, Price, Quantity Equilibria}

The demand for knowledge may be assessed with proxies such as the distribution of the employed labor force by the main economic sectors of activity following the International Labor Organization terminology [61]. See Table 5, below. This corresponds to an increase in the demand from previous estimates and an indicator of the strengthening of the Portuguese Knowledge Economy. The supply of knowledge has been increasing, as shown in the growing number of graduates generated by the educational system and of skilled workers generated by the training system. .

The joint consideration of supply and demand means that Portugal saw and increase in the level of the equilibria during the forty years, from low medium to medium high. In the process the quantity of knowledge in the economy grew. Regarding the price, became less, relatively, as the levels of education became more accessible.

Table 5. Demand for knowledge [61].

\begin{tabular}{lc}
\hline & $\mathbf{2 0 1 7}$ \\
\hline Labor force & 4806 \\
\hline High skills: Managers, professionals and technicians & 1777 \\
\hline Middle skills: clerical support workers, services and sales workers and craft workers & 1807 \\
\hline Low skills: plant workers and workers in elementary occupations & 1222 \\
\hline
\end{tabular}

\section{4-3-3- Needs}

The increase in the level of equilibria as described in the previous section decreased because as the average level of knowledge increased the needs became lower. 


\section{4-3-4- Reflection}

The operations described in section 4.2, that happened in the context described in section 4.1 were massive, and had massive impacts: in one hand the operations effectively created a market of knowledge, described in 4.3.1, 4.3.2 and 4.3.3. In the other hand, the operations had the massive outcomes described in 4.3.2. All in all it may be said that from 1974 to 2017 and particularly from 1986 to 2017 KM related operations led to the instauration of a middle to high level of KE in Portugal.

\section{5- Discussion}

Table 6 summarizes the paper and describes the evolution from a low skills equilibria in 1974, to a high low equilibria in 2017. This positive evolution is remarkable and illustrates the emergence of the Portuguese Knowledge Economy and of KM in the country.

The Portuguese case of KM just described in section 4 may be defined as a success story, Or, even better, is the repetition of a success story, given that it is well known that in the Renaissance Portugal dominated the world due to the use of knowledge (see 4.1). Empires rise and fall, and the fall of Portugal, first in the 17th century and then in the 19th century, was due to the failure to master the knew forms of knowledge, namely the agricultural and the industrial revolution. Portugal had a rather late try at the first and the second Industrial revolution, but, quite curiously, seems to be being much more successful in the third industrial revolution. This happens because, by coincidence, the changes in context that happened in Portugal, first with the democratic revolution of 1974, then with the adhesion to the European Communities in 1986 and even with the membership of the Eurozone in 2002, gave the country a stable, advanced and open setting in which the third industrial revolution could prosper. Quite crucially investing in knowledge, was one of the first social and economic priorities of the regime, and both the Portuguese government and the European Union funding bodies and law makers made a substantial force to improve knowledge in the country.

Table 6. Knowledge in Portugal.

\begin{tabular}{|c|c|c|c|c|}
\hline & 1974 & 1986 & 2002 & 2017 \\
\hline Context Background & Dictatorship & Adhesion to the European Communities & Eurozone & Post-Troika \\
\hline VET systems & Elitist & Being created & Booming & Consolidated \\
\hline Institutional Actors & Families & Government & Europe & Companies \\
\hline Political Context & Fascism & Democracy & Social Democracy & Mr Trump \\
\hline Legislative Documents & Constitution & Europe & Lisbon Strategy & Treaty of Lisbon \\
\hline Eligibility & Strict & Young & Large & Unemployed \\
\hline Programs & Few & Some & A lot & Many \\
\hline Evaluation & Inexistent & Numeric & Program centered & Scientific \\
\hline Investments & Inexistent & Small & Medium & Large \\
\hline Stocks & Scarce & Small & Medium & Large \\
\hline Returns & Small & Medium & Large & Very large \\
\hline Demand & Small & Medium & Large & Very large \\
\hline Supply & Small & Medium & Large & Very large \\
\hline Price & Very High & High & Medium & Low \\
\hline Needs & Very high & High & Medium & Medium \\
\hline Assessment & Low equilibria & Middle low equilibria & Middle Equilibria & High low equilibria \\
\hline
\end{tabular}

In the last 50 years the country went from being the center of a Colonial Empire under a dictatorship to a member thee most advanced form of economic integration built since WWII; and after that event the country endured a crisis of which it survived being in 2019 an economy much centered in services and tourism. At the same time the vocational and educational training system was first for a few, then created in a new version, more democratic and less elitist and then developed, and finally consolidated. This fact is the basis for the slow but sure transition of the country from a low skills equilibria to a middle low, a middle and a high low one.

The transformation is explained by some decisive facts. Using knowledge, and with the willingness of the Portuguese government, the cooperation of the national social forces, and much support from external actors like the EU and also some multinationals that decisively invested in the country, creating skilled jobs, generating income and exports, it was possible for the country to finally "take off" in economic terms [62]. That long awaited (at least since 
WWII) emergence happened between 1986 and 1998, and was followed, in due course, by a phase of instauration of a "mass consumption" [62] society, which, as all the dreams that come true, ended with a massive crisis of debt around 2010. That crisis of debt was solved by massive austerity measures, between 2011 and 2014. And afterwards the country began a new era of development, based on Tourism [63]. Quite interestingly in all the phases (take-off, mass consumption, debt crisis, recession, recovery), the level of knowledge of the Portuguese society never ceased to increase. And it may be envisaged that when Portugal will be a high skilled equilibria regarding knowledge, it will become also a mature business society [62]. Crucially, knowledge will be the focus and helm of the process.

During that long process of knowledge growth, the context changed from a dictatorial and old-fashioned regime in which knowledge was luxury and families were the main investor, to first a nascent democracy state guided, then an European region and finally a global player in which companies have much importance in the investment in knowledge. During that long process investments went to few, elitist and non-evaluated to many, dedicated mostly to the unemployed, ruled by European Treaties and evaluated scientifically.

All the change in context and investment resulted in a massive change in outcomes - investment stocks and flows increased, quantities of demanded and supplied spiraled, price decreased but needs when comparing the country with the world leaders, decreased.

\section{6- Conclusion}

Portugal was traditionally an elitist society concerning knowledge. For centuries, knowledge was provided to the elites, informally, or abroad [9] even if in the meantime the country went to be the first global power, due to the use of knowledge and human resources, in the Renaissance [3]. But, the lack of the democratization and the elitism of the system of KM, led to the country being surpassed by other potencies that invested more in KM like the Netherlands first, and then the UK, the USA, France and many other countries. Therefore, in 1974, when the current history phase of KM began, Portugal was a middle income country, with a low knowledge base, which continued to be elitist, informal and relying in the outside world [9]. The last 45 years saw the situation of the country and of KM in the country change drastically and both the situations are linked. In one hand the country went through a process of political, economic, social and cultural change [64]. All those changes ended up transforming Portugal from an old Empire in 1973 to a region of the Eurozone in 2002 a fact that still continues in 2019. This was massive change in a very small period of time. Quite interestingly also, there the situation regarding the knowledge base and use also changed massively, even if slowly. In short Portugal went from a low equilibria economy in terms of knowledge to a transitional situation between the middle and the high equilibria, improvements being done every year and the situation of the younger generations being closer to the world class standards.

Specifically, as described in section 4.1, the context changed for the better, with actors that promote and welcome knowledge; also as described in section 4.2 the interventions were augmented immensely due to the efforts of many actors, from national government, companies and families to international bodies like the EU and MNCs; finally results began to show up and the country nowadays is having good times, due to massive use of knowledge, lately related to tourism. All this has the implication that knowledge still has to continue to be priority for the country, and much studies should be done on the topic. For the future, it will be important to monitor the situation and to do updated analysis like this one, performing also more detailed studies and also comparative studies.

\section{7- Conflict of Interest}

The author declares that there is no conflict of interests regarding the publication of this manuscript. In addition, the ethical issues, including plagiarism, informed consent, misconduct, data fabrication and/or falsification, double publication and/or submission, and redundancies have been completely observed by the authors.

\section{8- References}

[1] Bounfour, Ahmed and Edvinsson, L. "Intellectual Capital for Communities" Oxford (June 25, 2012 ): 368. doi: $10.4324 / 9780080478562$.

[2] Nonaka, Ikujiro, and Hirotaka Takeuchi. "The knowledge-creating company: How Japanese companies create the dynamics of innovation." Oxford University Press, (1995).

[3] Eduardo Tomé "Human Resources, Globalization and Globalization: The Portuguese Case" 8th International Conference on Human Resource Development Research \& Practice across Europe, de 26-8, June (2007).

[4] Becker, Gary S. "Human Capital: A Theoretical and Empirical Analysis, with Special Reference to Education", University of Chicago Press (1993). doi:10.7208/chicago/9780226041223.001.0001.

[5] Frank, Robert H. "Microeconomics and behavior." Boston: McGraw-Hill Irwin, (2008).

[6] Tomé, Eduardo. "Critical Knowledge Management: An Insight into the Literature." In European Conference on Knowledge Management, pp. 864-XXVII. Academic Conferences International Limited, (2018). 
[7] David Ashton and Francis Green. "Education, Training and the Global Economy" Comparative Education Review 41, no. 3 (August 1997): 348-350. doi:10.1086/447457.

[8] B-on. B-online, Available online: https://www.b-on.pt/ (accessed on December 2019).

[9] Tome, Eduardo. "IC and KM in a Macroeconomic Perspective: The Portuguese Case." International Journal of Learning and Intellectual Capital 5, no. 1 (2008): 7. doi:10.1504/ijlic.2008.018879.

[10] Chagas Lopes, Margarida. "The development of knowledge in Portugal: a slow and unsustainable progress." IUP Journal of Knowledge Management 12, no.3 (2014): 42-61.

[11] dos Santos Ferreira, Vítor Hugo, and Ana Santos. "The impact of knowledge management in innovation performance in the Leiria region." In European Conference on Intangibles and Intellectual Capital, Academic Conferences International Limited, (2014): 24-32.

[12] Rodrigues, Katia, and Eduardo Tomé. "Knowledge cities: A Portuguese case." In Proceedings of the European Conference on Intellectual Capital, Cyprus, (2011): 350-358.

[13] Torres, Ana Isabel, Silvana Santos Ferraz, and Helena Santos-Rodrigues. "The Impact of Knowledge Management Factors in Organizational Sustainable Competitive Advantage.” Journal of Intellectual Capital 19, no. 2 (March 12, 2018 ): $453-472$. doi:10.1108/jic-12-2016-0143.

[14] Teixeira, Eduardo Kunzel, Mirian Oliveira, and Carla Curado. "Linking Knowledge Management Processes to Innovation." Management Research Review 43, no. 3 (October 5, 2019): 332-349. doi:10.1108/mrr-10-2018-0391.

[15] Santos, Gilberto, Sergio Gomes, Vitor Braga, Alexandra Braga, Vanda Lima, Paulo Teixeira, and José Carlos Sá. "Value Creation through Quality and Innovation - a Case Study on Portugal.” The TQM Journal 31, no. 6 (November 29, 2019): 928947. doi:10.1108/tqm-12-2018-0223.

[16] Piteira, Margarida, and Jorge Gomes. "The Innovation Lessons: Organizational Narratives of Applied Knowledge in Technology-Based Organizations." In European Conference on Knowledge Management, vol. 2. Academic Conferences International Limited, (2014); 802-810.

[17] Almeida, Fernando, Emanuel Miranda, and João Falcão. "Challenges and Facilitators Practices for Knowledge Management in Large-Scale Scrum Teams.” Journal of Information Technology Case and Application Research 21, no. 2 (April 3, 2019): 90102. doi:10.1080/15228053.2019.1637087.

[18] Nunes, Frederico, and Carmina Simion. "Knowledge Management Perspectives: The Portuguese MNCs of Romania and Poland." In European Conference on Knowledge Management, vol. 2. Academic Conferences International Limited, (2014): 740-747.

[19] Martins, Dora, and Eduardo Tomé. "Knowledge management in multinational companies: the repatriates' role in the competitive advantage in subsidiaries." In European Conference on Knowledge Management, vol. 2. Academic Conferences and Publishing International Limited, (2014): 628-636.

[20] Brito, Elisabeth, Leonor Cardoso, and Catarina Ramalho. "Knowledge Management in local government sector: The role of the Quality Certification." In European Conference on Intellectual Capital, vol. 2, (2010): 127-166.

[21] Brito, Elisabeth, and Leonor Cardoso. "Knowledge management processes in the Portuguese local government sector." In Proceedings of the 13th European Conference on Knowledge Management, vol. 1. Universidad Politécnica de Cartagena: Academic Publishing, (2012): 135-151.

[22] Marques, Carla Susana, Gina Santos, Vanessa Marques, and Eleusina Ramos. "The impact of knowledge creation, acquisition and transfer on innovation in the healthcare sector." In European Conference on Knowledge Management. Academic Conferences International Limited, (2018): 494-502.

[23] Cruz, Sofia Gaspar, and Maria Manuela Frederico Ferreira. "Gestão Do Conhecimento Em Instituições de Saúde Portuguesas." Revista Brasileira de Enfermagem 69, no. 3 (June 2016): 492-499. doi:10.1590/0034-7167.2016690311i.

[24] Lopes-Costa, Jose Alberto, and Antonio Munoz-Canavate. "Relational Capital and Organizational Performance in the Portuguese Hotel Sector (NUTS II Lisbon)." Procedia Economics and Finance 26 (2015): 64-71. doi:10.1016/s22125671(15)00839-4.

[25] Oliveira, ER De, and Paula Rodrigues. "Measuring sustainability and sustainable knowledge management: Presenting a case for the tourism sector in Portugal." In Proceedings of the European Conference on Knowledge Management, ECKM 2, no. 1995, (2010): 805-813.

[26] Almeida, Sofia; de Moraes, Michelle Lins; Campos, Ana Cláudia. "Absorptive Capacity, Explicit and Implicit Knowledge Sharing Practices within Consortia." Proceedings of the 20th European Conference on Knowledge Management (September 5, 2019): 27-32. doi:10.34190/km.19.061. 
[27] Eiriz, Vasco, Jorge Simões, and Miguel Gonçalves. "Obstáculos à gestão do conhecimento nas escolas de gestão e economia do ensino superior público em Portugal." Comportamento organizacional e gestão 13, no. 2 (2007): 153-167.

[28] Price, Heather E., and Kristen Weatherby. "The Global Teaching Profession: How Treating Teachers as Knowledge Workers Improves the Esteem of the Teaching Profession." School Effectiveness and School Improvement 29, no. 1 (November 30 , 2017): 113-149. doi:10.1080/09243453.2017.1394882.

[29] Vale, Mário, and Luís Carvalho. "Knowledge Networks and Processes of Anchoring in Portuguese Biotechnology.” Regional Studies 47, no. 7 (July 2013): 1018-1033. doi:10.1080/00343404.2011.644237.

[30] Rădulescu, Ion-Răzvan, Carmen Ghițuleasa, Emilia Visileanu, Ana Dias, Zoran Stjepanovic, Roberto Vannucci, and Mirela Blaga. "Logical and Sequential e-Learning Content for Supporting Specialists in Textile Enterprises." eLearning \& Software for Education 3 (2019): 418-424.

[31] Loforte Ribeiro, Francisco. "Enhancing Knowledge Management in Construction Firms." Construction Innovation 9, no. 3 (July 10, 2009): 268-284. doi:10.1108/14714170910973493.

[32] Mendonca, Joana, Rui Baptista, and Paulo Conde. "A Map of the Knowledge Bases for the Chemical Industry.” International Journal of Technology, Policy and Management 7, no. 3 (2007): 245-262. doi:10.1504/ijtpm.2007.015109.

[33] Rocha, Felipe de Sequeira, Leonor Cardoso, and Nuria Tordera. "The importance of organizational commitment to knowledge management." Comportamento organizacional e gestão 14, no. 2 (2008): 211-232.

[34] Cardoso, Leonor, and Andreia Meireles. "Role of organizational commitment in knowledge management: exploring a relationship." In Proceedings of the 11th European Conference on Knowledge Management, University of Lusiada, Vila Nova de Famalicao, Lisbon, 2-3 September, (2010): 209-217.

[35] Figueiredo, Elisa; Pais, Leonor; Mónico, Lisete. "The Perspective of Human Resource Management Practices as Determinants of Knowledge Management Processes." Proceedings of the 20th European Conference on Knowledge Management (September 5, 2019): 336-343. doi:10.34190/km.19.240.

[36] Figueiredo, Elisa, Leonor Pais, Samuel Monteiro, and Lisete Mónico. "The Role of Human Resource Management in Knowledge Management: The cases of Training and Career Management." Proceedings of the European Conference on Knowledge Management (2014): 353-361.

[37] Garavan, Thomas, McCarthy, A., \& Morley, M. "Global Human Resource Development: Regional and country perspectives." London: Routledge (February 5, 2016). doi:10.4324/9781315818177.

[38] Tomé, Eduardo. "European Social Fund in Portugal: a Complex Question for Human Resource Development.” Edited by Thomas N. Garavan. European Journal of Training and Development 36, no. 2/3 (April 6, 2012): $179-194$. doi:10.1108/03090591211204706.

[39] Tomé, Eduardo. "The European Social Fund: a Very Specific Case Instrument of HRD Policy.” European Journal of Training and Development 37, no. 4 (June 3, 2013): 336-356. doi:10.1108/03090591311319762.

[40] Tomé, Eduardo, and Apoorva Goyal. "Human Capital, HRD and VET: The Case of India." European Journal of Training and Development 39, no. 7 (August 3, 2015): 586-609. doi:10.1108/ejtd-10-2014-0069.

[41] Page, M., "The First Global Village," (Campo das Letras, 2006). 7th Edition, Lisbon, Portugal, in English ISBN13:9789724613130

[42] Prodata Statistics on Portuguese Education. Available online: https://www.pordata.pt/ (accessed on December 2019).

[43] World Bank, World Economic Indicators, 1975, Washington, USA.

[44] World Bank, World Economic Indicators, 1987, Washington, USA.

[45] World Bank. World Economic Indicators, 2002, Washington, USA.

[46] World Bank, World Economic Indicators, 2018, Washington, USA.

[47] OECD. Education at Glance, 2018, Paris.

[48] European Commission the ESF in Portugal. Available online: http://ec.europa.eu/esf/main.jsp?catId=394 (accessed on 10 July 2019).

[49] European Commission, Structural Funds 2014-2020 (ERDF and ESF) eligibility: Portugal. Available online: https://ec.europa.eu/regional_policy/en/information/publications/maps/2014/structural-funds-2014-2020-erdf-and-esfeligibility-portugal (accessed on 10 July 2019).

[50] EHEA European Higher Education Area and Bologna Process. Available online: http://www.ehea.info/ (accessed on 10 July 2019).

[51] Parlamento., Constituição da Republica Portuguesa. Available online: https://www.parlamento.pt/Legislacao/Paginas/ 
ConstituicaoRepublicaPortuguesa.aspx (accessed on 10 July 2019).

[52] DGES, Maiores de 23 anos. Available online: https://www.dges.gov.pt/pt/pagina/maiores-de-23-anos (accessed on 10 July 2019).

[53] Qualifica (2019) Programa Quaiifica. Available online: https://www.qualifica.gov.pt/ (accessed on 10 July 2019).

[54] Esping-Andersen, Gosta. "The three worlds of welfare capitalism." Princeton University Press, (1990).

[55] Novas Oportunidades 2005-2010. Available online: http://www.novasoportunidades.gov.pt/np4/16 (accessed on 10 July 2019).

[56] Rodrigues, Maria João, ed. "The new knowledge economy in Europe: A strategy for international competitiveness and social cohesion." Edward Elgar Publishing Company, (2002).

[57] European Parliament, The Treaty of Lisbon. Available online: http://www.europarl.europa.eu/factsheets/en/sheet/5/the-treatyof-lisbon (accessed on 10 July 2019).

[58] Oliveira, Manuela, Carlos Vieira, and Isabel Vieira. "Modelling Demand for Higher Education: A Partial Least-Squares Analysis of Portugal." European Journal of Higher Education 5, no. 4 (October 2015): 388-406. doi:10.1080/21568235.2015.1084589.

[59] Amorim, José Pedro. "Mature Students' Access to Higher Education: A Critical Analysis of the Impact of the 23+ Policy in Portugal.” European Journal of Education 53, no. 3 (August 20, 2018): 393-413. doi:10.1111/ejed.12283.

[60] Sin, Cristina, Orlanda Tavares, and Alberto Amaral. "The Impact of Programme Accreditation on Portuguese Higher Education Provision." Assessment \& Evaluation in Higher Education 42, no. 6 (July 3, 2016): 860-871. doi:10.1080/02602938.2016.1203860.

[61] ILOSTAT - Statistics on Employment - Employment by sex and economic activity -- ILO modelled estimates - $2019,2020$. Available online: https://ilostat.ilo.org/topics/employment/ (accessed on 30 October 2020).

[62] Rostow, W. W. "The Stages of Economic Growth" Cambridge University Press (February 22, 1991). doi:10.1017/cbo9780511625824.

[63] Tomé, Eduardo. "Tourism in Portugal-Between the Bubble and the Miracle." In International Conference on Tourism Research. Academic Conferences International Limited, (2018): 151-X.

[64] Eduardo Tomé, Portugal 1974-2014: de um império a uma região numa união monetária. Congresso - Portugal 40 anos de Democracia. Porto, Março, (2014). 